\title{
Improving the Capacity of Private Universities Management
}

\author{
Faurani Santi Singagerda* \\ Faculty of Economics University of Sang Bumi Ruwa Jurai \\ Bandar Lampung \\ fsingagerda@saburai.ac.id
}

\author{
Mery Berlian \\ Faculty of Mathematics and Science \\ Indonesia Open University UPBJJ Pekanbaru
}

\begin{abstract}
This research explain the influence of leadership style and organizational culture to the motivation and the implications of the lecturer performance in private universities, by taking research location in Bandar Lampung, Indonesia. The Private university is an academic institution managed by individual /foundation certain characteristics, generally have not adequate academic capacity than the public university, so that it adversely affects the academic performance, especially the performance of lecturers. By taking a sample of 244 samples from 30 Private Universities in Bandar Lampung, where the samples are taken to obtain data relating to the variables of leadership style, organizational culture, motivation and performance of lecturers will be observed. Meanwhile, a descriptive quantitative is the methodolgy that is used in this research, and Structural Equation Model is an analytical tool to find the influence and the causal relationship between those variables. The results showed that the leadership style, organizational culture, and motivation should be carried out simultaneously, in order to improve the performance of lecturers. Therefore, academic management must be able to motivate the lecturers to increase the professionalism, and academic career development. In addition, to increase the motivation of lecturers, leaders must be able to develop the existing system through training programs, and policy to encourage the lecturers improving education.
\end{abstract}

Keywords-Management, Motivation, Leadership, Organization Culture, Work Performance

\section{INTRODUCTION}

In the globalization era, the entire of National Higher Education should be ready to compete with universities in Southeast Asia, Asia, and even the world. Lecturers as educators have the main task of transforming, developing and disseminating science, technology, and the arts through education, research, and community service. So that a lecturer has a central and strategic role to determine the height of the low quality of a university. [1]

In this case, the Foundation (as the owner of Private Universities) should be able to manage the Human Resources, including work load of activities, such as: planning, implementing learning process, evaluating of learning, guiding and training, conducts research, perform additional tasks, and giving services to community. Therefore, the requirement of an ideal lecturer not only obtained by calculating the needs of faculty and teaching work load to the total load of the lecturers itself, but also how many the foundation lecturer who holds master and doctorate degree, or those who are studying. But in reality, the system of planning and development being done is still not meet the expectations in terms of quantity, quality, and qualification.

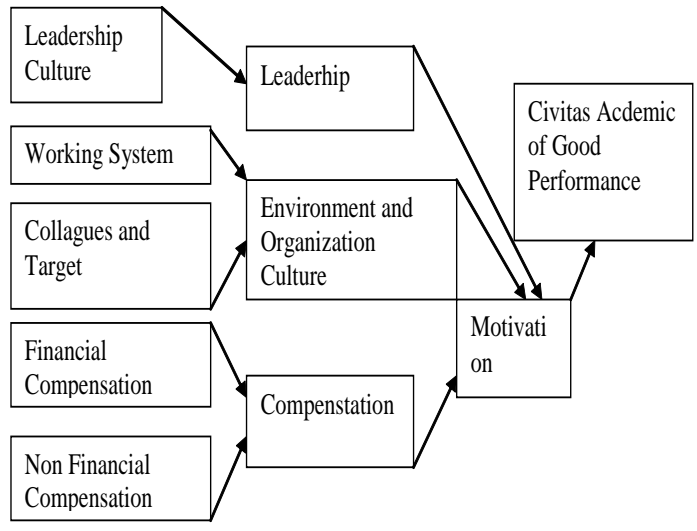

Source : Jurnal Kopertis Wilayah II, (2014)

Fig 1. Support Civitas Academic Performance

In order to support the improvement of the quality, planning, and development of lecturers including recruitment process, therefore the improvement of qualification of lecturers based on educational background should be be done carefully, to ensure quality development of education on subject and learning process effectively and efficiently. As the figure 1 showed, the quality of education for lecturers in Private University is determined by the quality of services provided by the University, where production process is a process of education services, while the quality of education is the result of the services provided by the Private University. Institutions of higher education or university can be described as a place where students gain confidence (through quality services), and faculty or lecturers whose get good ratings from users of education services. [2]

This statement shows the importance of role of the lecturers as a party who provides educational, and student services that will determine sustainability and success of a higher education institution. Therefore, lecturer is one of the essential components of higher education system. [3] Roles of duties and responsibilities of the lecturers are very significant in realizing the objective of national education, ie educating the nation, improve human quality (including the quality of faith and piety, character, and the mastery of 
science, technology, and art), as well as bring Indonesia into more developed, fair, prosperous and civilized.

In order to support the improvement of the quality, planning, and development of lecturers including recruitment process, therefore the improvement of qualification of lecturers based on educational background should be be done carefully, to ensure quality development of education on subject and learning process effectively and efficiently. As the figure 1 showed, the quality of education for lecturers in Private University is determined by the quality of services provided by the University, where production process is a process of education services, while the quality of education is the result of the services provided by the Private University.
This statement shows the importance of role of the lecturers as a party who provides educational, and student services that will determine sustainability and success of a higher education institution. Roles of duties and responsibilities of the lecturers are very significant in realizing the objective of national education, ie educating the nation, improve human quality (including faith and piety, character, and the mastery of science, technology, and art), as well as bring Indonesia into more developed, fair, prosperous and civilized. Therefore, to achieve good performance, the lecturers must have a high motivation, adequate competence, good leadership, and the support of the working environment.

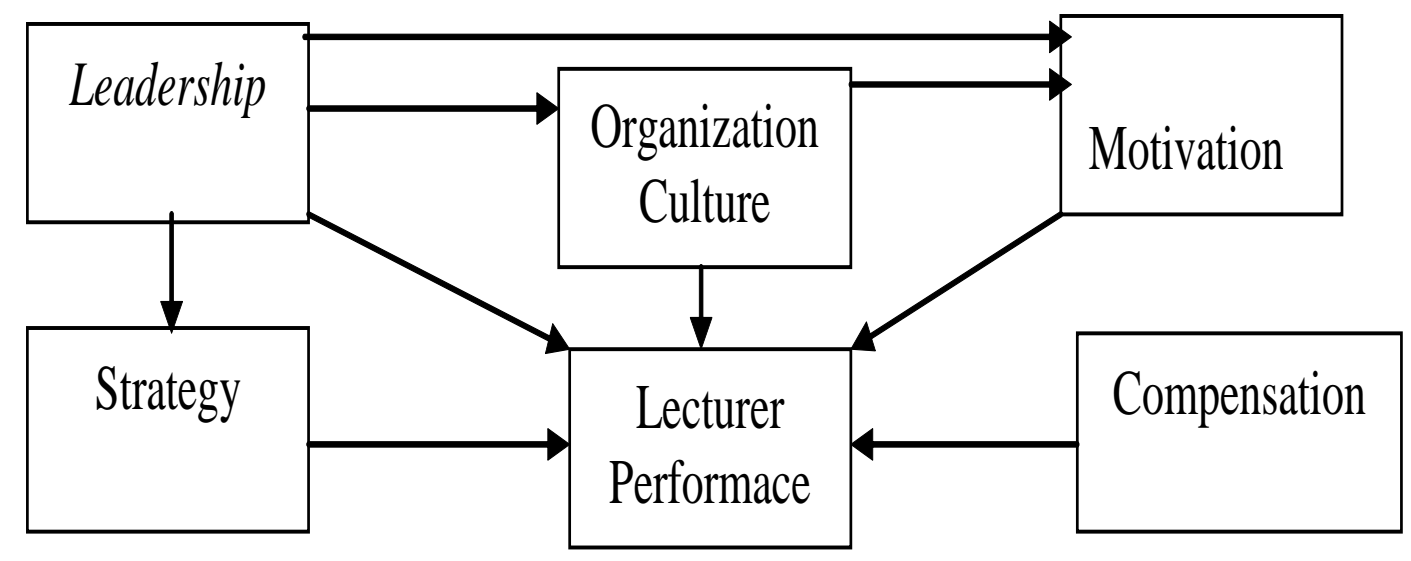

Source : Jurnal Kopertis wilayah II, (2014)

Fig 2. Factors Affecting Performance suspected Lecturer

As figure 2 showed to create lecturer performance is not easy, because of the performance of the good lecturer could be created if the variables that influence, such as work motivation, leadership, and organizational culture can be accommodated properly and accepted by all the lecturers in an organization Private University. [4] in [5] suggests that organizational performance depends on the performance of the individual, or in other words, individual performance will contribute to the performance of the organization, which means that the behavior of organizational members either individually or in groups give power over the organization's performance, because the motivation will affect the performance of the organization.

The performance in this study is something that occurs due to the influence of the organization's leaders, either actively or passively. A leader active is someone were directly lead organizations, but leaders passive is someone who is not directly in place or involved in the organization. Here are described in the table some evidence to suggest that the importance of leadership in an organization, especially the University of Sang Bumi Ruwa Jurai (as a sample) to show how far the ability of employees and lecturers in completing the work, as follows:

TABLE 1. EMPLOYEE PERFORMANCE OF UNIVERSITY OF
\begin{tabular}{l|l|l|l}
\multicolumn{4}{c}{ SANG BUMI RUWA JURAI } \\
\hline $\begin{array}{l}\text { Duration of } \\
\text { Leader in } \\
\text { Office }\end{array}$ & $\begin{array}{l}\text { Total } \\
\text { Work } \\
\text { Complete }\end{array}$ & $\begin{array}{l}\text { Unavailable } \\
\text { leader in } \\
\text { office }\end{array}$ & $\begin{array}{l}\text { Total } \\
\text { Work } \\
\text { Complete }\end{array}$ \\
\hline $\begin{array}{l}1 \text { day in office } \\
1 \text { week in } \\
\text { office }\end{array}$ & $\begin{array}{l}15 \text { jobs } \\
45 \text { jobs }\end{array}$ & $\begin{array}{l}1 \text { day in out } \\
\text { office } \\
1 \text { week out } \\
\text { office }\end{array}$ & $\begin{array}{l}10 \text { jobs } \\
35 \text { jobs }\end{array}$ \\
Inccidentally & 20 Jobs & Outing &
\end{tabular}

Source: University of Sang Bumi Ruwa Jurai, (2015)

Table 1 shows that there's unique in completing routine work either with or without a leader. According to the table, if the leader is in place the work will be completed, and if the leader is not in place then many work are not resolved properly. Therefore, based on the phenomenon, a leader of Private University needs to steer the motivation to create organizations conditions through establishment of a work culture so that lecturers feel motivated to work harder, and finally the performance achieved is also high. Motivation should be directed to be 
priority strategy and can not given to any lecturers with different kinds. So that the strategy can be well received by the lecturers.

Beside motivation and organization culture, leadership is also one element of significant value in the college management system. Leadership is an ability to influence a group towards the achievement of objectives. Definition of leadership shows that it is needed to improve the competitiveness of the organization on an ongoing basis. Leadership is a process in which a person can be a leader through a continuous activity that may affect the followers in order to achieve the objective of the organization.

Based on the background described above, therefore it can be identified several issues may affect the motivation and performance lecturers foundation in Private Universities in Bandar Lampung are found that most of leader in Private Universities in Bandar Lampung has a weak leadership style, so the motivation and performance of lecturers are become low and has implications for output produced; there is a problem in an effort to improve performance lecturer in order to provide optimum performance [6], because of high dependence of the completion of a job so that it is needed supervision activities; the presence of leadership affects to completion of the quality of work and target; most of the organizational culture is not good, so that lecturers have low motivation and implied to the low performance of lecturer; the motivation of lecturers in Private University in Bandar Lampung is less precise, this condition will imply for the low performance; career path is less clear, so it can affect to job satisfaction low and implications for the low performance of lecturers; the level of discipline held lecturer Private University low, so the impact on the quality of teaching on campus; and interpersonal communication is ineffective among the organizations in Private University, that affect the lecturer performance.

Therefore, the objective of research can be explained as follows: Analyze the influence of leadership style and organizational culture to the motivation of lecturers remained the foundation Private University in Bandar Lampung; and analyze the contribution of leadership styles, organizational culture, and work motivation on the performance of foundation lecturer in Private University in Bandar Lampung.

\section{THEORY OVERVIEW}

Leadership style shows, directly or indirectly, about the conviction of a leader of the ability of subordinates [7]. That is, the style of leadership is the behavior and strategy, as a result of a combination of philosophies, skills, personality traits, attitudes, which are often applied a leader when he tried to influence the performance of subordinates [8]. In psychology, an important aspect in the work of leadership is the extent to which leaders are able to influence the work motivation of human resources to enable them to work productively with full responsibility [9].

According to [10], style of leadership are patterns of behavior that are preferred by leaders in the process of directing and influencing workers. From that sense it was revealed that what was done by the employer have an influence on subordinates, which can generate motivation and excitement of working and vice versa.

Organizational culture is a tool in interpreting life and behavior of the organization [11]. A strong culture is a powerful tool to direct and motivate behavior [9], because it helps employees to do their jobs better, so that every employee needs to understand the culture and how that culture implemented.

Organizational culture is a system of shared meaning held by members that distinguishes the organization from other organizations [12]. Thus the stronger the culture of the organization can have a direct impact on employee motivation.

Research [13] within the scope of the service industry further demonstrate the critical role of transformational leadership in improving employee performance. [14], empirically also found transformational leadership influence employee performance.

Jennifer Chatman and Bersade in [15], take sample of 102 financial services firm in the United States. The findings related to the strong organizational culture are: (1) strong organizational culture helps the performance of business organizations because it creates a level that is remarkable about the employees; (2) strong organizational culture, helps the organization's performance, because it provides structure and the control you need without having to rely on formal rigid bureaucracy and that can suppress the growth of motivation and innovation.

When leaders show good leadership, employees will have the opportunity to learn the proper behavior to deal with the job.

Based on [16], organization of culture is reflected in the work culture can be recognized by its form in the form of values contained therein, institution or system of work, as well as the attitudes and behavior of the employees in this case the lecturer who carry it out. So that, work culture of lecturer will be defined as the attitudes and behavior of individuals and groups of lecturers based on values that are believed to be true and it has become the nature and enforcement customs duties and daily work.

This is a continuous process where the member of organizations express their concern about the organization, their success and sustainable progress. As described that motivation is the driving force that creates the excitement of one's work, to cooperate, work effectively, and integrated with all resources to find satisfaction. Thus the attitudes and behaviors of lecturers who have high motivation at work can influence the increased of performance [17]. It means that the lecturers performance can be measured from the work achieved by the lecturer, work effectiveness and efficiency, and productivity in carrying out the activities, programs, policies.

As has been disclosed that the leadership styles of behavior and strategies, as a result of a combination of philosophies, skills, personality traits, attitudes, which are 
often applied a leader when he tried to influence the performance of subordinates.

According to [18], in addition to the leadership style organizational culture can also affect the performance of employees. Formed a strong culture within an organization will directly form the system followed by the employees and can improve employee performance.

\section{METHODOLOGY}

This research is quantitative and descriptive research. The main objective of this study was to identify the causal relationship among various variables. According to [19], descriptive approach used to obtain information about the symptoms at the time of the study, therefore the essential elements that must be considered in the survey is the process of making the questionnaire, the determination of the list of questions, as well as the format of the questionnaire design.

This research is quantitative and descriptive research. The main objective of this study was to identify the causal relationship among various variables., therefore the essential elements that must be considered in the survey is the process of making the questionnaire, the determination of the list of questions, as well as the format of the questionnaire design [20]. Beside that, the study also will prove a causal relationship between the independent variable leadership, and organizational culture; work motivation as intervening variable; and dependent variable of lecturers performance. Using random sampling method, sample data taken as many as 244 of the 974 population foundation lecturer in private Universities in Bandar Lampung, and by using structural equation model of the second order as an analytical tool that will be done to make conclusions.

While the variables of this study consisted of a latent variable (unobserved variable) and the manifest variables (observed variables) are formed on the two structures. In the first sub-structure, there are two latent exogenous variables are independent variables affect the dependent variable consists of the leadership style and organizational culture. While the latent endogenous variable on the first structure is the motivation to work. While the sub-structure of the two, there are three exogenous latent variable that is the style of leadership, organizational culture and work motivation with endogenous latent variable lecturer performance.

To formulate statements within the questionnaire, first thing to do is to determine the research instrument used to measure the variables observed. From this research instrument, the researchers will develop the instruments in the form of operational definitions [20], where the operational definition is the development of the theories underlying the variables to be measured. The operational definitions of the variables to be observed are:

\section{Leadership Styles.}

Conceptual definition of the variable leadership style is: "The means used by a leader in urging subordinates or employees within the organization to achieve organizational objectives through change".
While the definition of Operations in the style of Leadership is to measure force of Leadership in this study was developed from situational leadership theory by Paul Hersey and Ken Blanchard in [21] consisting of four (4) dimensions of leadership styles, namely: Telling-Directing, selling-Coaching, Supporting and Delegating-Participating.

2. Organizational Culture.

Definition Conceptual variable Organizational Culture is: "A pattern of basic assumptions invented, discovered or developed by certain groups as learning to overcome the problem of external adaptation and internal integration are authorized and implemented properly and therefore taught / passed on to new members as the proper way to understand, to think, and feel familiar with the matter ", (Schein in. [22]

Conceptual definition of the variable Work motivation is: "The conditions that influence evokes, directing and maintaining positive and productive behaviors associated with the work environment". [23]

4. Performance Lecturer.

Conceptual Definition of lecturers Performance are: "The perfomance is the quality and quantity can be achieved by a teacher in carrying out tasks according to the responsibility given to him". [24] And Operational Definitions on faculty performance variable is operationally measured using four (4) dimensions derived from the Tri Dharma Perguruan Tinggi ( three University Roles and Performance); namely: education and teaching, research and scientific publications, Dedication to the community, and Support Activities.

In this study analysis is qualitative and quantitative analysis, where the qualitative analysis performed using theories, literature and studies that are relevant to the topic of this study. While quantitative analysis is by using analysis of SEM (Structural Equation Modelling) with the model used in this study is a model of causality or influence the relationship between the variables used.

To create a complete modeling of the following measures should be taken:

1) Develop a theory based on a model, where the SEM is based on a causal relationship, it means that changes in one variable is assumed to be changed in other variables,

2) Establish a flowchart of a causal relationship to describe the relationship between variables in a flow chart that can be especially helpful in describing a series of relationships between constructs and theoretical models that have been built in the first phase. As in preparing flowcharts, it will describe relationship between constructs with arrows. The arrows depicted straight stated that a direct causal relationship between the construct with other constructs. Here, the construct means is exogenous construct designated by the line with one arrowhead, b. Constructs endogenous variable where all factors that predicted by a single or multiple constructs. Constructs can predict endogenous construct at one or several other endogenous, but exogenous constructs can only be associated or causality with 


\section{$\therefore$ ATLANTIS \\ PRESS}

endogenous constructs. Further research can be seen flowchart on figure 3 , and then

3) Change the flow diagram into structural and measurement model equations. In this third step and a structural equation model of the specific measurement ready made is with making and changing the flowchart into the measurement model. Thus, from the 3 step above, the equations are built from converted flowchart consisting of:

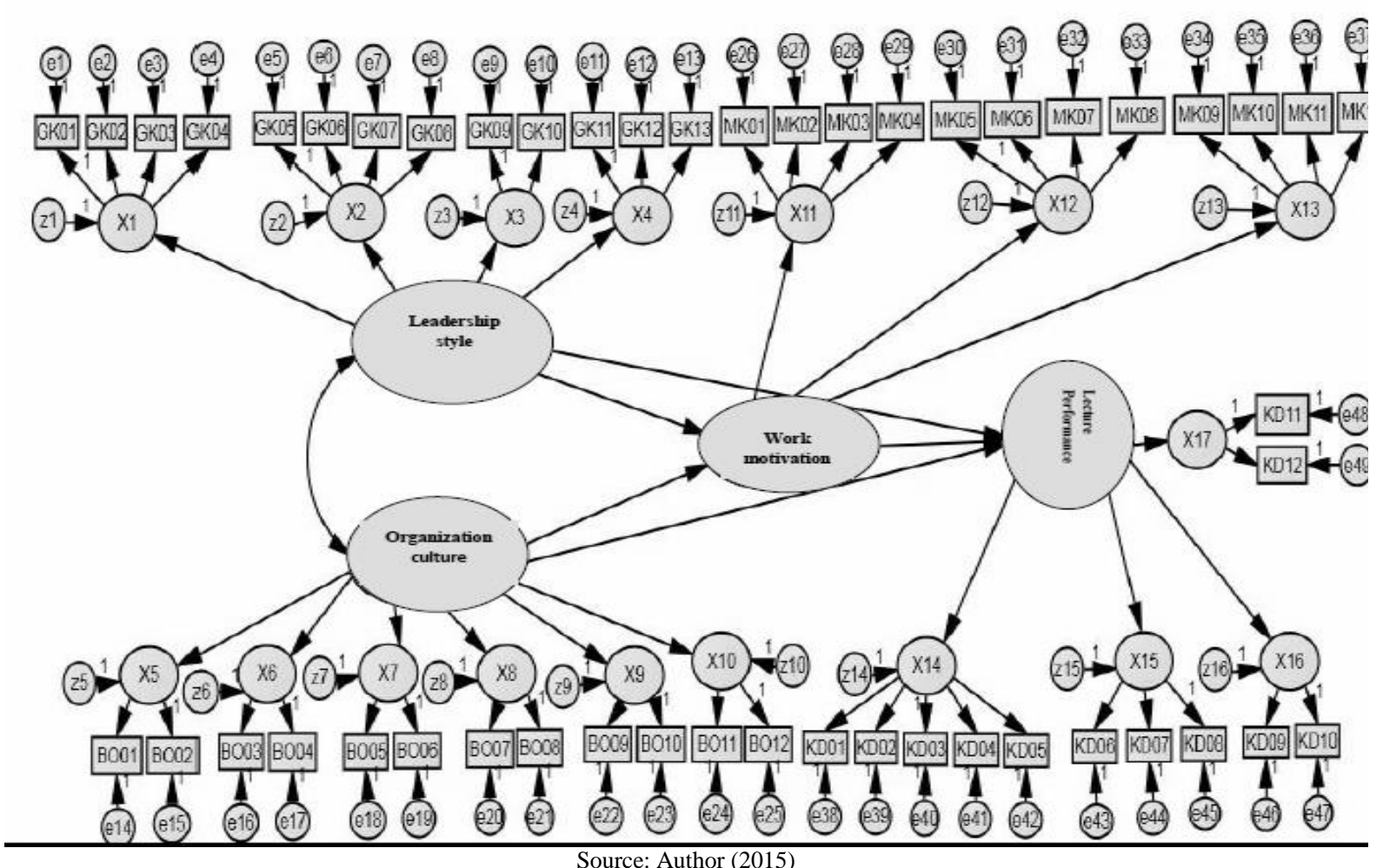

Figure 3. Conceptual Research Flow Chart

Note :

$$
\begin{aligned}
& \mathrm{X}_{1}=\text { Telling } \\
& \mathrm{X}_{2}=\text { Selling } \\
& \mathrm{X}_{3}=\text { Participating } \\
& \mathrm{X}_{4}=\text { Delegating } \\
& \mathrm{X}_{5}=\text { Organization Value } \\
& \mathrm{X}_{6}=\text { Management Support } \\
& \mathrm{X}_{7}=\text { Reward System } \\
& \mathrm{X}_{8}=\text { Tolerance } \\
& \mathrm{X}_{9}=\text { Lists of Jobs }
\end{aligned}
$$

a. Structural equation, formulated to express causality, that each endogenous construct a separate dependent variable. While the independent variables are all constructs that have lines with arrows that connect to the endogenous construct with the following guidelines:

Endogenous Variable $=$ Endogenous Variable + Exogenous Variable + Error

Thus the structural equation is:

Sub-structure 1:

Motivation $=\beta 1$ Leadership Style $+\beta 2$ Cultural Organization $+\delta 1$

$\begin{array}{rll}X_{10} & = & \text { Team Orientation } \\ X_{11} & = & \text { Award } \\ X_{12} & = & \text { Afilliation } \\ X_{13} & = & \text { Power } \\ X_{14} & = & \text { Education and Training } \\ X_{15} & = & \text { Research and Publication } \\ X_{16} & = & \text { Community Service } \\ X_{17} & = & \text { Supporting Activities }\end{array}$

Sub Structure 2:

Performance $=\beta 1$ Leadership Style+ $\beta 2$ Cultural Organization $+\beta 3$ Motivation $+\delta 1$

Note:

$\beta=$ regression weight,$\delta=$ disturbance term

b. Equation specification measurement model on the specification of this model where the variable is determined which measure constructs, as well as define a series of matrices that show the correlation between the hypothesized constructs or variables. 


\section{ATLANTIS
PRESS}

Measurement Models in this study can be defined as a process modeling is used to confirm the dimensions used.

While the measurement model equations in this study as the following table:

Measurement Model:

Exogenous concept:

$\mathrm{X} 1=\lambda 1$ Leadership Style $+\varepsilon 1$

$\mathrm{X} 2=\lambda 2$ Leadership Style $+\varepsilon 2$

$\mathrm{X} 3=\lambda 3$ Leadership Style $+\varepsilon 3$

$\mathrm{X} 4=\lambda 4$ Leadership Style $+\varepsilon 4$

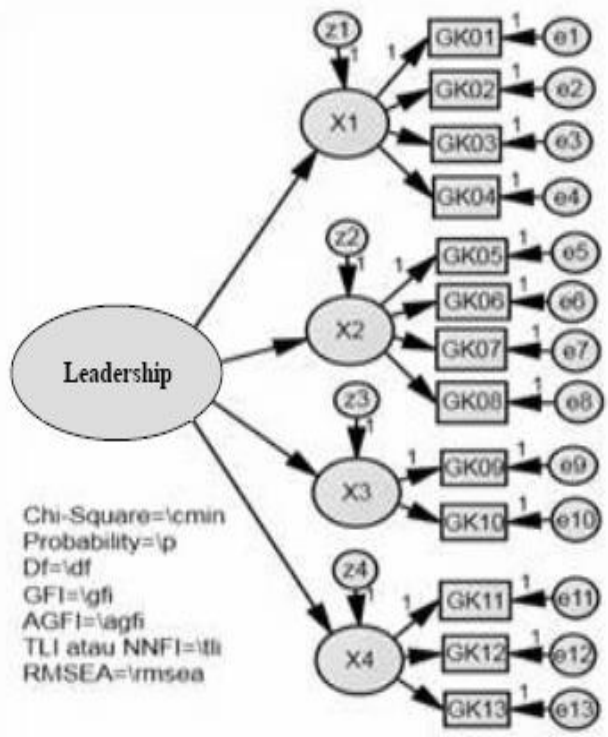

Source: Author data processed, (2015) Figure 4. CFA Leadership Style

Endogenous concept:

$\mathrm{X} 5=\lambda 5$ Cultural Organization $+\varepsilon 5$

$\mathrm{X} 6=\lambda 6$ Organizational Culture $+\varepsilon 6$

$\mathrm{X} 7=\lambda 7$ Cultural Organization $+\varepsilon 7$

$\mathrm{X} 8=\lambda 8$ Organizational Culture $+\varepsilon 8$

$\mathrm{X} 9=\lambda 9$ Cultural Organization $+\varepsilon 9$

$\mathrm{X} 10=\lambda 10$ Organizational Culture $+\varepsilon 10$

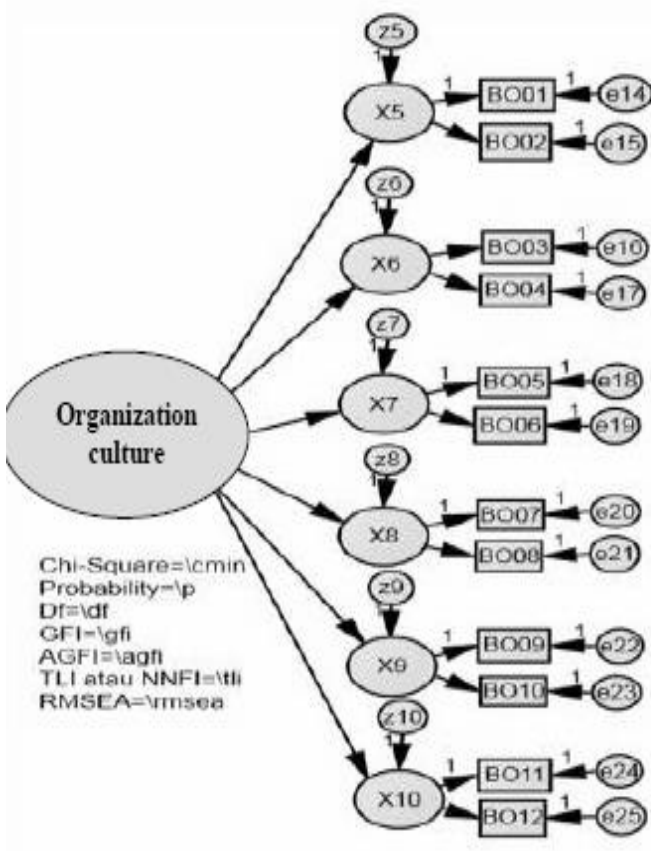

Source: Author data processed, (2015)

Figure 5. CFA Organizational Culture.

Endogenous concept:

$\mathrm{X} 11=\lambda 11$ Work Motivation $+\varepsilon 11$

$\lambda 12$ Work Motivation $+\varepsilon 12$

$\mathrm{X} 13=\lambda 13$ Work Motivation $+\varepsilon 13$

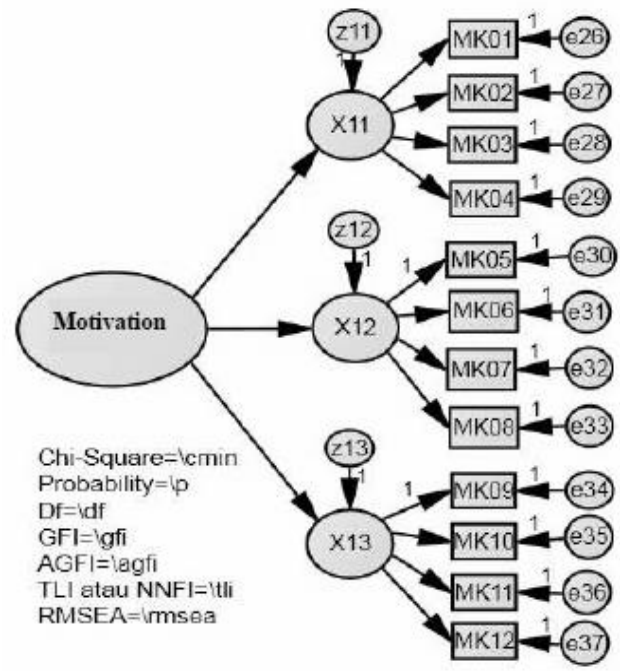

Source: Author data processed, (2015)

Figure 6. CFA Work Motivation.

Endogenous concept:

$\mathrm{X} 14=\lambda 14$ Lecturer Performance $+\varepsilon 14$

$\mathrm{X} 15=\lambda 15$ Lecturer Performance $+\varepsilon 15$

$\mathrm{X} 16=\lambda 16$ Lecturer Performance $+\varepsilon 16$

$\mathrm{X} 17=\lambda 17$ Lecturer Performance $+\varepsilon 17$ 


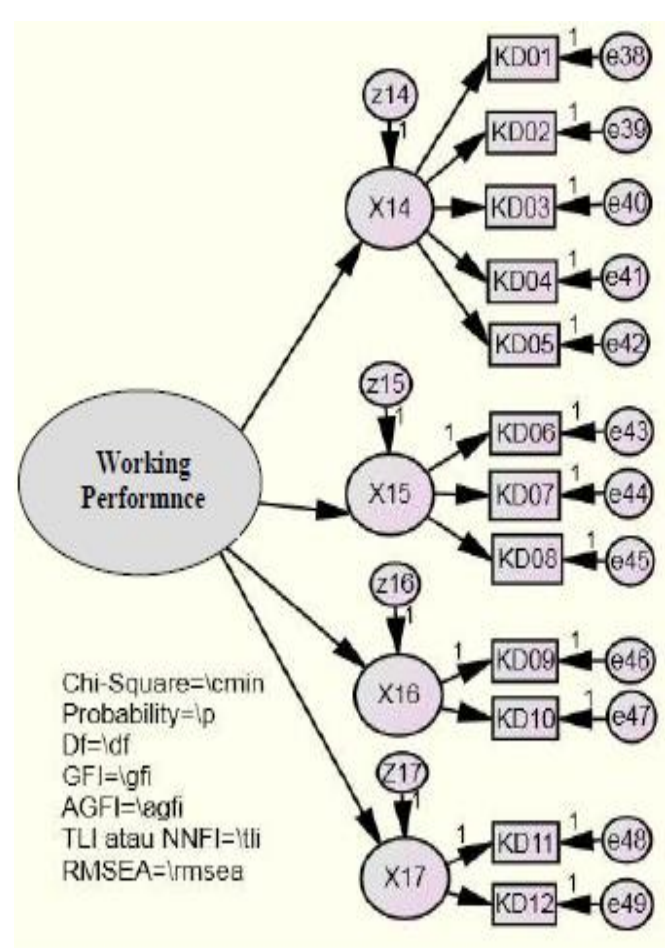

Source: Author data processed, (2015) Figure 7. CFA Work Performance

\section{Hypothesis}

As for the hypothesis of this study are as follows:

TABLE 2: HYPOTHESIS

\begin{tabular}{|c|c|c|c|}
\hline Hypothesis & & $\begin{array}{l}\text { Statment of } \\
\text { Hypothesis }\end{array}$ & Criteria \\
\hline \multirow[t]{2}{*}{1} & $\mathrm{H}_{0}$ & $\begin{array}{l}\text { There is no influence } \\
\text { leadership style and } \\
\text { organizational culture } \\
\text { on work motivation } \\
\text { remains the foundation } \\
\text { Private University } \\
\text { lecturer in Bandar } \\
\text { Lampung }\end{array}$ & $\begin{array}{l}\text { If } C R<1,96 \text { or } \\
\text { probability }(P)> \\
0,05\end{array}$ \\
\hline & $\mathrm{H}_{1}$ & $\begin{array}{l}\text { There is the influence of } \\
\text { leadership style and } \\
\text { organizational culture } \\
\text { on work motivation } \\
\text { remains the foundation } \\
\text { Private University } \\
\text { lecturer in Bandar } \\
\text { Lampung. }\end{array}$ & $\begin{array}{l}\text { If } \mathrm{CR}<1,96 \text { or } \\
\text { probability }(\mathrm{P})> \\
0,05\end{array}$ \\
\hline \multirow[t]{2}{*}{2} & $\mathrm{H}_{0}$ & $\begin{array}{l}\text { There is no influence of } \\
\text { leadership style, } \\
\text { motivation, and } \\
\text { organizational culture } \\
\text { on the performance of } \\
\text { tenured faculty } \\
\text { foundation } \\
\text { University in Bandar } \\
\text { Lampung. }\end{array}$ & $\begin{array}{l}\text { If } \mathrm{CR}<1,96 \text { or } \\
\text { probability }(\mathrm{P})> \\
0,05\end{array}$ \\
\hline & $\mathrm{H}_{1}$ & $\begin{array}{l}\text { There is the influence of } \\
\text { leadership style, } \\
\text { motivation, and } \\
\text { organizational culture to } \\
\text { lecturer foundation } \\
\text { performance in Private } \\
\text { University in Bandar } \\
\text { Lampung. }\end{array}$ & $\begin{array}{l}\text { If } \mathrm{CR}<1,96 \text { or } \\
\text { probability }(\mathrm{P})> \\
0,05\end{array}$ \\
\hline
\end{tabular}

\section{ANALYSIS AND DISCUSSION}

In this study, the full model equations using the SEM program LISREL 8:30 acquired three models trajectory diagram, ie: standardized models, respectively as shown in the following figure: 


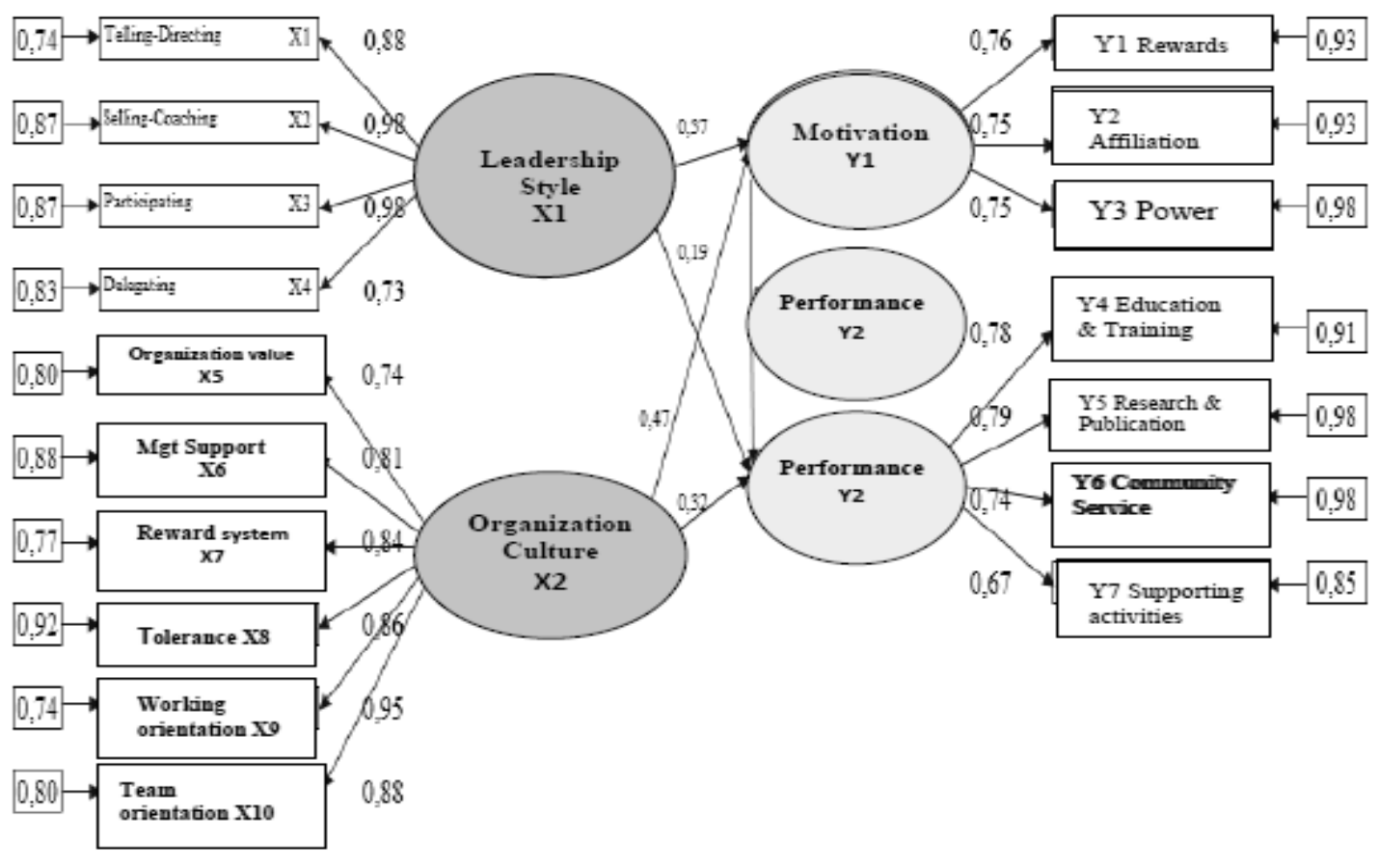

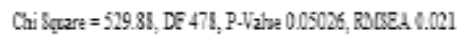

Source: Author data processed, (2015)

Figure 8. Full SEM Model Diagram

Further testing the hypothesis is as follows:

Sub-Structural Equation (unstandardized Estimates):

MOTIVATION $=0.37 *$ LDRSTYLE $+0.47 *$ CULTURE, Errorvar $=0.45, R^{2}=0.55$
$(0.072)$
$(0.10)$
5.12
4.68

Structural equation (unstandardized Estimates):

PERFORMANCE $=0.40 *$ MOTIVATION $+0.19 *$ LDRSTYLE $+0.32 *$ CULTURE, Errorvar $=0.38, R^{2}=0.62$
$(0.094)$
$(0.076)$
$(0.089)$
4.28
2.45
3.54

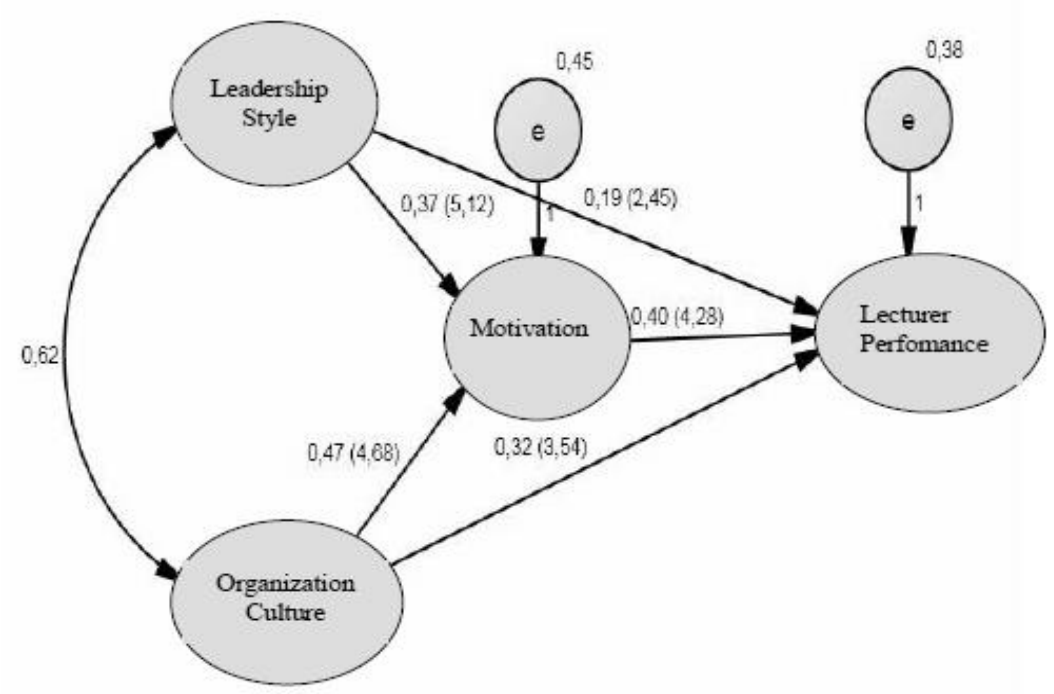

Source: Author data processed, (2015)

Figure 9. Regression Coefficients and t value Full SEM Model Has Been Fit (unstandardized Estimates). 
Hypothesis Testing 1.

Based on the hypothesis outlined based on the results of the analysis conducted obtained the following results:

H1: There is the influence of leadership style and organizational culture on work motivation remains the lecturer of foundation in Private University in Bandar Lampung.

Because the value of CR or t-value 5.26 then Ho is rejected, and the conclusion is received $\mathrm{H} 1$. $\mathrm{H} 1$ statement is: "There is a positive and significant effect of leadership style and organizational culture on work motivation remains the foundation Private University lecturer in Bandar Lampung".

[25] argues that leadership is the ability to influence others (staff) such that the other person is willing to do the will of the leader though personally it might not be her . Similarly, [26] argues that leadership is a process of influencing the behavior of others to behave as would be desired.

While the organizational culture are the norms, values, assumptions, beliefs, philosophy, customs organizations, and so on that are developed in a long time by the founders, leaders, and members of the organization are socialized and taught to new members as well as applied in the organization's activities so as to affect the pattern think the attitude and behavior of members of the organization in producing the products, serve customers and achieve organizational objectives[27]. In general, people motivated by cultural influences their behavior. Culture requires individuals to behave and give instructions to them to know what it must be followed and studied. The condition also applies in an organization. [28]

Then motivation is the driving force that led to someone willing and willing to exert the ability in the form of expertise and skills, energy and time to organize various activities that are the responsibility and fulfill its obligations in order to achieve the objectives and targets of activities that have been determined. [29]

Hypothesis testing 2

Results of testing the second hypothesis which shows that there is a positive and significant effect of leadership style and organizational culture on work motivation the foundation lecturer in Private University in Bandar Lampung turned out in line with and reinforces the findings of previous studies conducted by several researchers such as: [30], which generally resulted in the finding that the leadership style or leadership and organizational culture together positive effect on work motivation.

From the above discussion it can be concluded that leadership style and organizational culture has contributed to the motivation to work, because the Full Feasibility Test Model was significant or meet the criteria for testing. Thus the efforts made by the Private University in the city of Bandar Lampung to increase the motivation of foundation lecturers can through improved leadership styles and organizational culture within the Private University in the city of Bandar Lampung.

Based on the hypothesis outlined based on the results of the analysis conducted obtained the following results:

H1: There is a contribution of leadership, organizational culture and work motivation on the performance of foundation lecturer in Private University in Bandar Lampung. It means that full Feasibility Test Model SEM indicate that the full model is significant, it can be concluded that: "There is the contribution of leadership, organizational culture and work motivation on the performance of foundation lecturer in Private University in Bandar Lampung".

Based on the results of testing hypothesis 2 which says that there is a contribution of leadership styles, organizational culture and motivation to work together on the performance of foundation lecturer in Private University in Bandar Lampung turned out in line with and reinforces the findings of previous studies conducted by several researchers such as: [31] which would generally produce findings that the style of leadership or leadership, organizational culture and motivation to work together to contribute to the performance.

From the above discussion it can be concluded that the style of leadership, organizational culture and work motivation has contributed to the performance of foundation lecturer in Private University in Bandar Lampung, because Feasibility Full Model was significant or meet the criteria for testing. Thus the efforts to be made by Private University in the city of Bandar Lampung to improve the performance of tenured foundation lecturer can through improved leadership styles, organizational culture and lecturer work motivation in the Private University in Bandar Lampung.

\section{Effect of Direct, Indirect and Total}

1. Direct Impact.

Further analysis of the discussion to see how strong the influence of exogenous variables on the intervening variables and the endogenous variable, either directly, or indirectly. Thus will be able to define a clear strategy in order to improve employee performance. The result of the calculation of the effect of direct, indirect and total effect is as: 


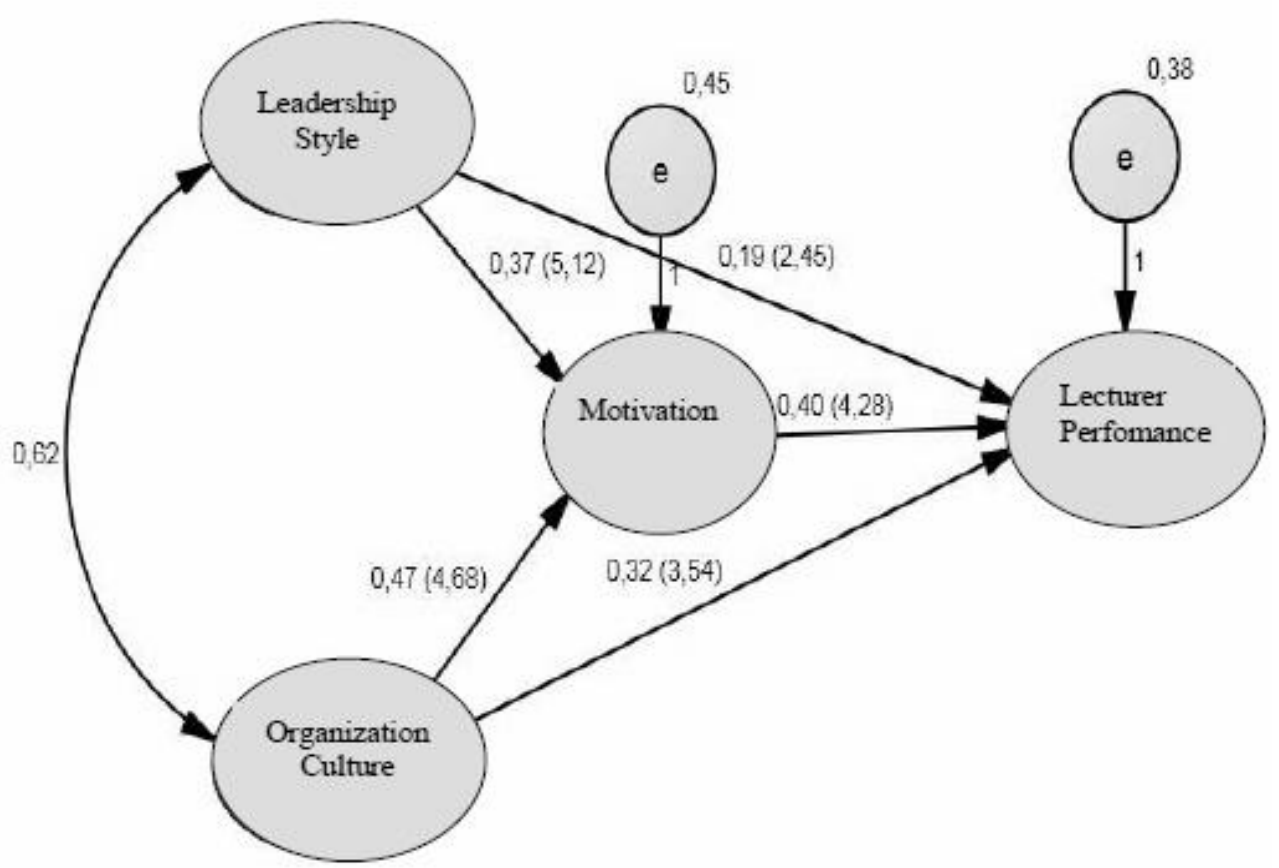

Source: Author data processed, (2015)

Figure 10. Coefficient of Direct Impact SEM Model

a. Direct Impact Sub-Structural

In sub-structural equation, from figure 11, it can be seen that the contribution of the organizational culture is more dominant than the leadership style to the work motivation. Contributions of organizational culture on work motivation of 0.47 . While the contribution of leadership style to the work motivation of 0.37 . So that efforts Private University in Bandar Lampung to increase the motivation of foundation lecturers and improve organizational culture than increasing leadership style led Private University in Bandar Lampung.

b. Direct Impact of Structural

In the structural equation, the figure 11 can be seen that motivation has contributed the most dominant contribution to the performance (compare to leadership style, and organizational culture). Contributions of work motivation is 0.40 , the organizational culture 0.32 ; and leadership style 0.19 on employee performance. Thus, to improve the performance of Foundation lecturer in Private
University in Bandar can be operated primarily through motivation, then the organizational culture, and leadership style of Private University in Bandar Lampung.

\section{Indirect Impact}

\begin{tabular}{c|c|c} 
& TABLE 3. INDIRECT IMPACT \\
\hline & Leadership Style & $\begin{array}{c}\text { Organization } \\
\text { Culture }\end{array}$ \\
\hline Motivation & - & - \\
\hline $\begin{array}{c}\text { Working } \\
\text { Performance }\end{array}$ & 0.15 & 0.19 \\
\hline \multicolumn{2}{c}{ Source: Processed Data (2015) }
\end{tabular}

Table 2 and figure 12 show the results of calculation of the contribution of leadership style and organizational culture on performance of lecturers. The result is a culture of the organization (0.19)> leadership style (0.15). That is indeed the foundation lecturers in Private University in Bandar Lampung more pleased enhanced organizational culture than the leadership style of leadership to improve performance. 


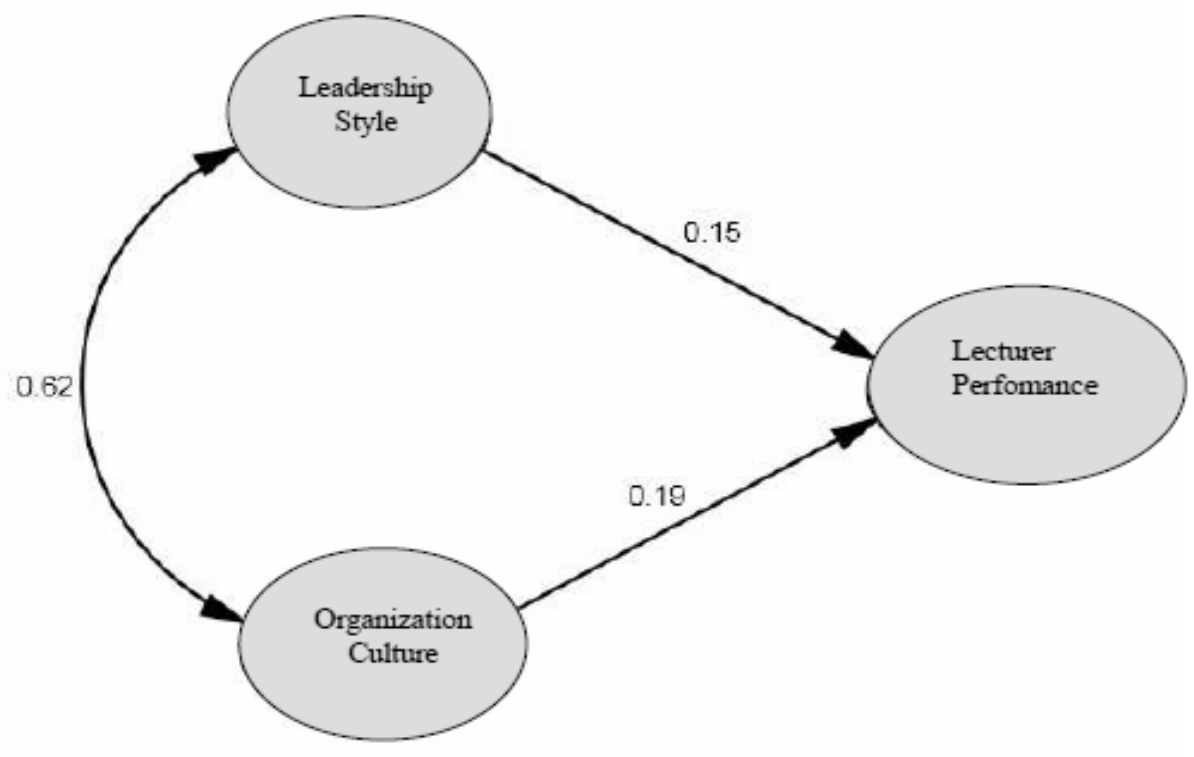

Source: Author data processed, (2015)

Figure 11. Coefficient of Indirect Influence SEM Model

\section{Total Impact}

\begin{tabular}{c|c|c}
\multicolumn{3}{c}{ TABLE 4. TOTAL EFFECT } \\
\hline & $\begin{array}{c}\text { Leadership } \\
\text { Style }\end{array}$ & $\begin{array}{c}\text { Organization } \\
\text { Culture }\end{array}$ \\
\hline Motivation & 0.37 & 0.47 \\
\hline $\begin{array}{c}\text { Working } \\
\text { Performance }\end{array}$ & 0.33 & 0.50 \\
\hline & Motivation & $\begin{array}{c}\text { Working } \\
\text { Performance }\end{array}$ \\
\hline Motivation & - & - \\
\hline $\begin{array}{c}\text { Working } \\
\text { Performance }\end{array}$ & 0.40 & - \\
\hline \multicolumn{2}{c}{ Source: Processed Data (2015) }
\end{tabular}

\section{a. Total Sub-Structural 1 Impact}

In sub-structural equation, from the table 3 and figure 13 can be seen that organizational culture has contributed a total of more dominant than the leadership style of work motivation. The total influence of organizational culture on work motivation of 0.47 . While the contribution of leadership style to the work motivation of 0.37 . So that the foundation lecturers motivation more dominant to improve the organizational culture than leadership style.

\section{b. Total Sub-Structural 1 Impact}

In sub-structural equation, from the table 3 and figure 13 can be seen that organizational culture has more dominant contribution than the leadership style to work motivation. The total influence of organizational culture on work motivation of 0.47 . While the contribution of leadership style to the work motivation of 0.37 . So that efforts Private University in Bandar Lampung to increase the motivation of lecturers remained dominant foundation improve organizational culture than improving leadership style.

\section{c. Effect of Total Structural}

In the structural equation, on the table 3 and figure 13, can be seen that organizational culture has the most dominant contribution to performance than leadership style and motivation. The net effect of 0.50 organizational culture, motivation of 0.40 while the leadership style of the performance of the lecturers 0.33 . Thus, to improve the performance of foundation lecturer in Private University in Bandar Lampung can be operated mainly through an increase in the organization's culture, motivate lecturers, and then apply the appropriate style of leadership. As for the work motivation can also be regarded as an intervening variable with a positive coefficient and big enough although it is not significant. So Private University in Bandar Lampung in improving the foundation lecturer performance can be through motivating the foundation lecturers, coupled with the improvement of the organizational culture and leadership style. 


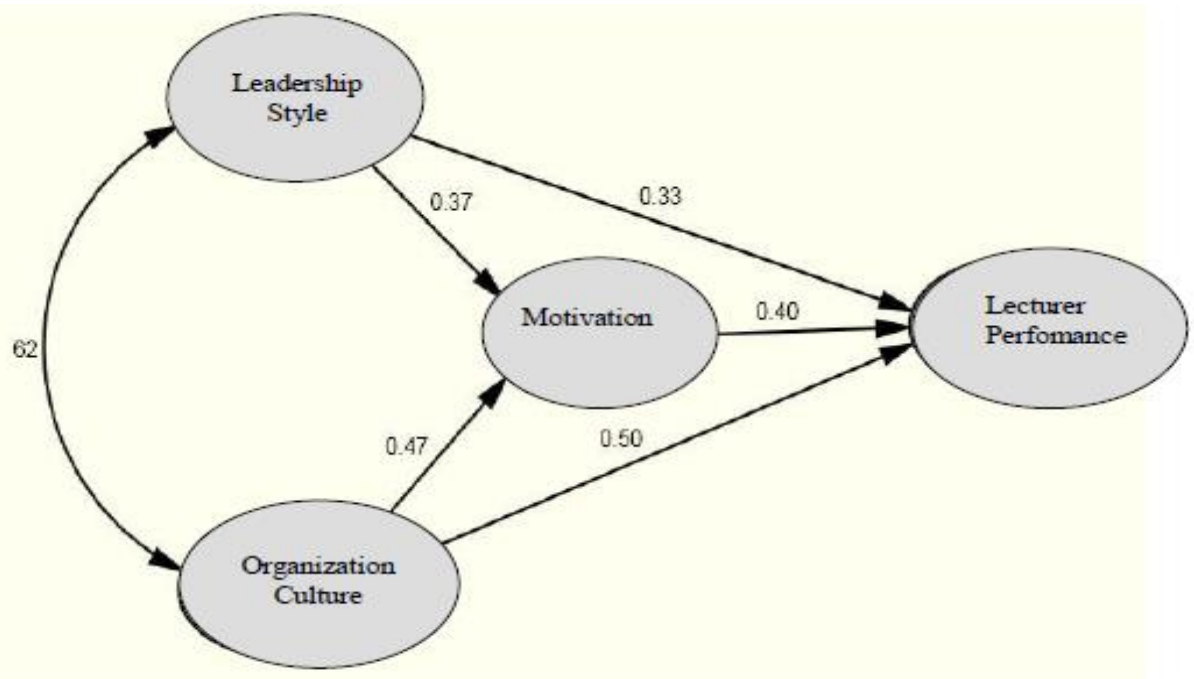

Source: Author data processed, (2015)

Figure 12. Total Influence Coefficients Model SEM

\section{CONCLUSIONS AND IMPLICATIONS}

\section{Conclusion}

Based on test results and statistical analysis of research data, it can take several conclusions as follows:

1. In sub-structure, leadership style and organizational culture positive and significant impact on work motivation of the foundation lecturer in Private University in Bandar Lampung and this is in line also with what is expressed by Bono, J.E. \& T.A. Judge in his research with the results of R-squared $=0.55$ and other factors remaining motivation will increase when there is a strong organizational culture and leadership in accordance with the model organsiasi culture. These findings prove that the motivation remains the foundation lecturer in Bandar Lampung Private University would increase if leaders Private University apply the appropriate style of leadership, supported and their efforts to change and strengthening the organizational culture.

2. In the structure, leadership style, organizational culture and work motivation lecturer positive and significant effect on the lecturer performance in Private University in Bandar Lampung. These findings prove that the efforts to improve the performance foundation lecturer in Private University in Bandar Lampung will happen if the leadership jointly implement appropriate style of leadership, backed by a strong organizational culture, as well as their motivation to work the lecturers were high. This conclusion is also in line with what is expressed by Smith, F Gerald and Hamlin. R on the model of organizational culture, leadership and motivation will improve lecturer performance, but there are other variables that influence.

\section{Implications}

1. In sub-structure, leadership style and organizational culture has a positive and significant contribution to the work motivation remains the foundation lecturer in Private University in Bandar Lampung. The policy implications of these findings are an attempt to increase the motivation of teachers can through apply the leadership style and culture simultaneously. Having regard to the indicators and dimensions have a coefficient $(\lambda)$ is dominant, then it needs to be improved variable dimensions and indicators of leadership style and organizational culture that is dominant, according to the table 5:47. (P. 174), namely: (1) indicators GK03 (0.87) $\rightarrow$ "Leaders establish good relations with staff", (dimension X1 = Telling Directing), (2) indicators GK $09(0.83) \rightarrow "$ leaders were able to motivate the lecturers ", (dimension X3 = Participating-Supporting), (3) an indicator BO04 $(0.87) \rightarrow$ " I am satisfied with the merit system implemented on the campus I ", (dimension X6 = the reward system), (4) indicator BO07 (0.82) $\rightarrow$ "If I make a mistake I immediately fix it" and (5) indicator BO08 (0.82) $\rightarrow$ "I have a willingness to learn" (dimension X8 = tolerance). So to increase the motivation of the foundation lecturers in Private University in Bandar Lampung, the leaders need to be in a better relationship, more motivated lecturers, improving existing merit system, conduct training and encouraging staff and lecturers to improve education independently.

2. In the structure, leadership style, organizational culture and work motivation of lecturers have a positive and significant contribution to the performance of foundation lecturer in Private University in Bandar Lampung. The policy implication of these findings is to improve the performance of lecturers, therefore leaders in several Private University in Bandar Lampung must carry out jointly ideal leadership style, organizational culture is dynamic, strong and high lecturers work motivation. Efforts through leadership style, it should be increased dimensions and indicators of leadership style variable that has a coefficient $(\lambda)$ is dominant, according to the table 5:47. (P. 174), namely: GK03 indicator $(0.87) \rightarrow$ "Leaders establish good relations with subordinates", (dimension X1 = Telling 
Directing) and indicators GK09 $\rightarrow$ "Leaders were able to motivate the lecturers", (dimension X3 = Participating Supporting). While simultaneously necessary efforts to improve the performance of lecturers through the organization's culture. It needs to be improved on the dimensions and indicators of organizational culture that has a coefficient $(\lambda)$ is dominant, according to the table 5:47. (P. 174), namely: BO04 indicator $(0.83) \rightarrow$ "I am satisfied with the system implemented on the campus I", (dimension X6 = The reward system) and indicators BO07 (0.82) $\rightarrow$ "If I make a mistake I immediate fix "and indicators BO08 (0.82) $\rightarrow$ " I have a willingness to learn "(dimension X8 = tolerance). So to increase the motivation of the foundation lecturer in Private University in Bandar Lampung, leaders need to further improve the existing merit system, conduct training and encouraging staff and faculty to improve education independently. While efforts to improve performance through work motivation, which is the work motivation variable indicator which has a coefficient $(\lambda)$ is dominant, according to the table 5:47. (P. 174), namely: MK09 indicator $(0.79) \rightarrow$ "I would like to occupy the highest offices in this campus" (dimension X6 = Power). So to improve the performance of the foundation lecturers in Private University Bandar Lampung through work motivation for this larger variable improve performance after mediating variables of leadership and cultural organizations exist in affect to performance. is that leaders need to further improve career development for their professors on average wanted to occupy the highest offices. Thus, in this managerial implications the motivation variables can be mediated with both variable Leadership and Cultural Organization in improving performance

These findings prove that the efforts to improve the performance of foundation lecturers in Private University in Bandar Lampung can be done if the leadership of simultaneously applying appropriate style of leadership, backed by a strong organizational culture, as well as their motivation to work the lecturers were high.

\section{REFERENCES}

[1] Smith, F Gerald. "Beyond Critical Thinking And Decision Making: Teaching Business Students How To Think". Journal of Management Education. Vol 27 (1), p 24-51. 2003

[2] McCarthy, A.M.\& Tucker, M.L."Encouraging Community Service Through Service Learning". Journal of Management Education. Vol.26 (6), p 629. 2002

[3] Hadari Nawawi \& Martini Hadari. "Kepemimpinan yang Efektif'. Yogyakarta: Gadjah Mada University Press. 2004

[4] Gibson, Donnelly. "Organisasi, Prilaku, Struktur, Proses". Jakarta: Erlangga. 1996

[5] Brahmasari, Ida Ayu. "Pengaruh Motivasi Kerja, Kepemimpinan, dan Budaya Organisasi Terhadap Kepuasan Kerja Karyawan Serta Dampaknya pada Kinerja Perusahaan (Studi Kasus pada PT. Hai Internasional Wiaratama Indonesia". Pasca Sarjana Universitas 17 Agustus. Surabaya. 2004. Available at: http://www.distrodoc.com/375204-al56.

[6] Khumaedi, Evawati. "Pengaruh Disiplin dan Motivasi Kerja Terhadap Kinerja Pegawai Pada Dinas Sentra Operasi Terminal PT. Angkasa Pura". Jurnal Ilmiah Manajemen dan Bisnis: Vol. 2 No. 1. 2014

[7] Sparks, J.R. \& Schenk, J.A. "Explaining Tthe Eeffects of Transformational leadership: An Investigation of The Effects of
Higher-Order Motives in Multilevel Marketing Organizations". Journal of Organizational Behavior. Vol 22(8), p 849-869. US: John Wiley \& Sons. 2001

[8] Hamlin. R. .’Towards a Universalistic Model of Leadership: a Comparative Study of British and American Empirically Derived Criteria of Managerial and Leadership Effectiveness". Working paper WP005/02, University of Wolverhampton. 2002. available http://asp2.wlv.ac.uk/wbs/documents/mrc/Working\%20Paper s\%202002/WP006 02 Hamlin.pdf. download at 27 March 2014

[9] Kamalian, A. R., Yaghoubi, N. M., \&Moloudi, J. "Survey of Relationship between Organizational Justice and Empowerment (A Case Study)". European Journal of Economics, Finance and Administrative Sciences, (24) p 165-171. 2010

[10] Stoner et.al. "Management". 6th Edition, Prentice Hall. London. 2000

[11] Anwar Prabu Mangkunegara. "Sumber Daya Manusia Perusahaan”. Remaja Rosdakarya: Bandung. 2005

[12] Robbins, Stephen P. "Organization Behavior". 13th Edition. Translation of Benyamin Molan, Indonesian Edition. PT Mancanan Jaya Cemerlang, Indonesia. 2007

[13] Gibson, Donnelly. "Organisasi, Prilaku, Struktur, Proses". Jakarta: Erlangga. 1996

[14] Bono, J.E. \& T.A. Judge. "Self-Concordance at Work: Toward Understanding the Motivational Effects of Transformational Leaders". Academy of Management Journal, 46 (5) p 554-57. 2003

[15] Abdul Rashid, M.Z., M. Sambasivan \& J. Johari. “The Influence of Corporate Culture and Organizational Commitment on Performance". Journal of Management Development. Vol. 22 (8) p 708-728. 2003

[16] Rouda, R \& Kusy, M. "Development of Human Resources: Beyond Training - a Perspective on Improving Organizations and People in The Paper Industry". Tappi Journal, 78(4), p. 263265. 1995

[17] Nilsen, Hallgeir. "Influence on Study Academic Behaviour Through Motivation, Self Eficacy and Value-Expectation: An Action Research Project to Improve Learning". Journal Informing Sience and Information Technology Vol 6. 2009. Available at: http://www. iisit.org/Vol6/IISITv6p545556Nilsen598.

[18] Richard C. Bell and Kuei-Mei Cheng. "Transformational Leadership and Organizational Effectiveness in Recreational Sports/ Fitness Programs". The Sport Journal 5 (2) p 18-2. 2002

[19] Indriantoro dan Supomo. "Metodologi Penelitan Bisnis untuk Akuntansi dan Manajemen”. Edisi Pertama. BPFE Yogyakarta. Yogyakarta. 1999

[20] Siniscalco, Maria Teresa \& Auriat, Nadia. "Questionnaire Design: Module 8". Series Editor: Kenneth. N Ross. UNESCO Intarnational Institute for Educational Planning. 2005. Available at: http://www.unesco.org/iiep/PDF/TR_Mods/Qu_Mod8.pdf. download at 04 August 2014

[21] Wirjana, Bernadine R, dan Supardo, Susilo. "Kepemimpinan, Dasar-Dasar dan Pengembangannya". Yogyakarta: CV. Andi Offset. 2005

[22] Tika, P. "Budaya Organisasi Dan Peningkatan Kinerja Perusahaan". PT. Bumi Aksara. Jakarta. 2006

[23] Mariam, Rani. "Pengaruh Gaya Kepemimpinan dan Budaya Organisasi terhadap Kinerja Karyawan Melalui Kepuasan Kerja Karyawan Studi pada Kantor Pusat PT. Asuransi Jasa Indonesia (PERSERO)". [disertation]. Universitas Diponegoro, Semarang. 2009

[24] Koesmono, Teman. "Pengaruh Budaya Organisasi terhadap Motivasi dan Kepuasan Kerja serta Kinerja pegawai pada Sub Sektor Industri Pengolahan Kayu Skala Menengah di Jawa Timur”. Jurnal Manajemen \& Kewirausahaan, 7 (2). 2005

[25] Siagian P. Sondang."Kiat Meningkatkan Produktivitas Kerja". Rineka Cipta. Jakarta. 2002

[26] Nimran, Umar. "Perilaku Organisasi". Cetakan Ketiga. CV. Citra Media. Surabaya. 2004

[27] Wirawan. "Budaya dan Iklim Organisasi. Teori, Aplikasi, dan Penelitian". Jakarta: Salemba Empat. 2007 
[28] Malayu S.P. “ Manajemen Dasar, Pengertian, dan Masalah”. Jakarta : PT. Bumi Aksara. 2011

[29] Suranto, A.W. "Komunikasi Interpersonal". Yogyakarta : Graha Ilmu. 2011

[30] Narimawati, Umi. "Riset Manajemen Sumber daya Manusia". Agung Media : Jakarta. 2007
[31] Widyatmini, and Hakim, Luqman. "Hubungan Kepemimpinan, Kompensasi, dan Kompetensi Terhadap Kinerja Pegawai Dinas Kesehatan Kota Depok". Jurnal Ekonomi Bisnis 2 (13) p 163 170. 2008

[32] http://www.jurnal.kopertis2.or.id

[33] http://www.saburai.ac.id 